Toxicon

March 2016, Volume 111, Pages 91-99

http://dx.doi.org/10.1016/j.toxicon.2015.12.018

http://archimer.ifremer.fr/doc/00302/41356/

(C) 2016 Elsevier Ltd. All rights reserved

\title{
First report of goniodomin A production by the dinoflagellate Alexandrium pseudogonyaulax developing in southern Mediterranean (Bizerte Lagoon, Tunisia)
}

\author{
Zmerli Triki Habiba ${ }^{1,{ }^{*}}$, Laabir Mohamed ${ }^{2}$, Moeller Peter ${ }^{3}$, Chomérat Nicolas $^{4}$, Kéfi Daly-Yahia Ons ${ }^{1}$
}

${ }^{1}$ Tunisian National Agronomic Institute (INAT), U.R Marine Biology (FST EI Manar I), IRESA - Carthage University, 43 Avenue Charles Nicolle, 1082 Tunis, Tunisia

${ }^{2}$ UMR 9190 MARBEC IRD-Ifremer-CNRS-Université de Montpellier, Place Eugène Bataillon, Case 093, 34095 Montpellier Cedex 5, France

${ }^{3}$ Toxin/Natural Products Chemistry Program, National Ocean Service/NOAA, Hollings Marine

Laboratory, 331 Fort Johnson Road, Charleston, SC 29412, USA

${ }^{4}$ IFREMER, Laboratoire Environnement et Ressources Bretagne Occidentale, Station de Biologie

Marine, Place de la Croix, 29900 Concarneau, France

* Corresponding author : Habiba Zmerli Triki, Tel.: +216 52612929. ;

email address : bibarouma@hotmail.fr

\begin{abstract}
:
The dinoflagellate Alexandrium pseudogonyaulax is widely distributed around the world including the Mediterranean waters. The objectives of this study were to determine the morphology and phylogenic affiliation of $A$. pseudogonyaulax strain isolated from Bizerte Lagoon (Mediterranean waters, Tunisia) and investigate its toxicity. Molecular analyses confirmed the morphological identification of the isolated strain (APBZ12) as A. pseudogonyaulax. Moreover, it showed that it is $100 \%$ identical with strains of this species found in New Zealand, Japan, China and North Sea (Norway and Denmark) suggesting that this species is cosmopolitan. Until now, no toxin studies have been conducted on fully characterized (morphologically and molecularly) A. pseudogonyaulax. Cellular toxin production was determined using high pressure liquid chromatography coupled to mass spectrometry (HPLC/MS). Results showed for the first time that $A$. pseudogonyaulax contains goniodomin A (GDA), a highly toxic macrolide polyether previously shown to be produced by two other dinoflagellate species Alexandrium monilatum (Hsia et al., 2006) and Alexandrium hiranoi (erroneously identified as A. pseudogonyaulax in Murakami et al., 1988) in American and Japanese waters, respectively. This biologically active toxin has been associated over decades with fish mortality. Our study showed that the cell extracts of APBZ12 showed an important bioactivity using GH4C1 rat pituitary cytotoxicity bioassay.
\end{abstract}




\section{Highlights}

1 A. pseudogonyaulax cysts have different morphotypes

2 Phylogenetic tree showed that this species is cosmopolitan.

2 GDA was exracted from $A$. pseudogonyaulax vegetative cells for the first time

3 A. pseudogonyaulax cell extract showed an important cytotoxicity

Keywords : Alexandrium pseudogonyaulax, goniodomin A, Mediterranean sea, Morphology, Phylogeny 
48

49

50

51

52

\section{INTRODUCTION}

Human health and the shellfish industries are increasingly and seriously threatened by toxins produced by harmful algal bloom (HAB) species. Alexandrium (Dinophyceae) is one of the major $\mathrm{HAB}$ genera considering its diversity, wide distribution and impact on the ecosystem and aquaculture activity. It presents an important toxigenic diversity by producing three different toxin families: Saxitoxins, Spirolides and Goniodomins (Anderson et al., 2012).

Goniodomin A (GDA) is a macrolide polyether, with important biological properties and is responsible for human illness and death of aquatic fauna. It has been shown that this toxin affects human cytoskeleton reorganization (Takeda et al., 2008), human brain cells, cardiac functioning (Mizuno et al., 1998, Matsunaga et al., 1999) and it also inhibits regeneration of blood vessels (angiogenesis) (Abe et al., 2002). Exposure to GDA resulted in paralysis and death of fish and mollusks (Sievers, 1969, Harding et al., 2009) after 24-48 h of exposure and was preceded by external signs of stress including reduced ventilation, inability to attach to hard substrates, periodic pumping of the opercular plate, and increased mucus production. It has been shown that the chain-forming dinoflagellate Alexandrium monilatum was probably associated to widespread discolored water and increased fish mortality in the Mississippi Sound and off the eastern and western coasts of Florida over 60-70 years (Howell, 1953). Hsia et al. (2006) by utilizing combined NMR spectroscopy and mass spectrometry structurally characterized GDA in A. monilatum cells. This toxin was shown to be released when cells were stressed or ruptured in response to mechanical stimulation as fresh water precipitation or a bloom termination (Connell and Cross 1950, Gates and Wilson 1960). Sharma et al. (1968) reported the isolation of GDA, an antifungal compound, from the dinoflagellate Goniodoma sp. which bloomed in a bay near la Paraguera, Puerto Rico. Murakami et al. (1988) isolated, in 1986, the active substance GDA from a rock pool at Jogashima (Japan) from a dinoflagellate identified by Kita et al. (1985) as Alexandrium 
73

74

75

76

77

78

79

80

81

82

83

84

85

86

87

88

89

90

91

92

93

94

95

96

97

pseudogonyaulax (syn. Goniodoma pseudogonyaulax). However, Kita and Fukuyo (1988)

considered that this GDA-producing dinoflagellate in Jogashim was misidentified as Alexandrium pseudogonyaulax and described it as Alexandrium hiranoi Kita and Fukuyo.

Alexandrium pseudongonyaulax is a brackish-neritic dinoflagellate that belongs to the subgenus Gessnerium (Balech, 1995). This species was originally described as Goniodoma pseudogonyaulax Biecheler from the Thau lagoon (Mediterranean, France) (Biecheler, 1952). This dinoflagellate is distributed worldwide including the Mediterranean Sea, Japanese coastal waters and the Gulf of Georgia in British Columbia (Biecheler, 1952, Montresor, 1995, Bravo et al., 2006, Daly Yahia-Kéfi et al., 2001, Turki, 2004, Klein et al., 2010) and has also been reported as a bloom-forming in the Norwegian Sea (Throndsen et al., 2007) and in Alfacs Bay (Bravo et al., 2006). Klein et al. (2010) mentioned that A. pseudogonyaulax could be responsible of harmful effects to high marine trophic levels but the toxigenic potential of this species remains unknown since no toxicological analyses nor toxin extraction and identification have been performed on fully characterized A. pseudogonyaulax strains. To our knowledge, no formal studies were undertaken on determination of A. pseudogonyaulax toxicity showing the presence of GDA. Zmerli Triki et al. (2014) reported that the average A. pseudogonyaulax resting cyst density across the whole Bizerte lagoon (Southern Mediterranean, Tunisia) was rather high, reaching 639 cysts $\mathrm{g}^{-1}$ of dry sediment (DS) suggesting that this species developed regularly in this lagoon. Cyst germination could initiate important toxic blooms when environmental conditions become favorable which in turn could affect marine ecosystem components and cultivated mollusks in this area. The present study aimed to 1) fully characterize A. pseudogonyaulax originating from Bizerte lagoon using morphological examination and ribotyping, 2) analyze the toxin content of this dinoflagellate by HPLC/MS and 3) investigate the bioactivity of A. pseudogonyaulax cell extract. 


\section{MATERIAL \& METHODS}

\subsection{Sediment sampling and natural resting cyst extraction}

101 Sediments were sampled by scuba divers using core samplers in July-August 2012 in Bizerte

102 lagoon $\left(37^{\circ} 8^{\prime}-37^{\circ} 14^{\prime} \mathrm{N}, 9^{\circ} 46^{\prime}-9^{\circ} 56^{\prime}\right.$ E) North-East Tunisia (Fig. 1). The surface layer of

103 sediment cores $(3 \mathrm{~cm})$ was sliced and stored at $4{ }^{\circ} \mathrm{C}$ in the dark for several days before

104 processing. For cyst extraction, one gram of wet sediment was suspended in $50 \mathrm{~mL}$ of

105 Filtered Sea Water (FSW) and sonicated for $3 \mathrm{~min}$. The mixture was sieved under $100 \mu \mathrm{m}$ and

$10620 \mu \mathrm{m}$ mesh because A. pseudogonyaulax cyst diameter was above $20 \mu \mathrm{m}$. The slurry

107 remaining on the $20 \mu \mathrm{m}$ mesh was recovered with FSW, then centrifuged (MIKRO 22R

108 HETTICH centrifuges) for $10 \mathrm{~min}$ at $4{ }^{\circ} \mathrm{C}$ and $3000 \mathrm{t} \cdot \mathrm{min}^{-1}$. Cysts were extracted from the

109 resulting pellet using density gradient method with Polytungstate Solution (PST) (Bolch,

110 1997). Cysts recovered in the supernatant phase after PST centrifugation were flushed several

111 times with FSW to remove PST then stored in dark at $4{ }^{\circ} \mathrm{C}$.

112

113 2.2. Morphological identification of A. pseudogonyaulax resting cysts

114 Resting cysts (RCs) identification was based on microscopic observation of the morphology

115 of the cysts and resulting vegetative cells obtained from excystment experiments.

116 Alexandrium pseudogonyaulax RCs were isolated into 96-culture plates (Nunc ${ }^{\mathrm{TM}}$ Delta

117 surface) filled with $200 \mu \mathrm{l}$ of Enriched Natural Sea Water (ENSW) culture medium (Harrison

118 et al., 1980) and incubated at $20{ }^{\circ} \mathrm{C}$, salinity of $34,100 \mu \mathrm{mol}$ photons $\mathrm{m}^{-2} \mathrm{~s}^{-1}$ and $12 \mathrm{~h}: 12 \mathrm{~h}$

119 light:dark ratio. When germination occurred, the morphology of the emerging vegetative cells

120 and empty cysts were examined using a light microscope and 100X magnification (Esselte

121 Leitz GmbH, Germany). Within the culture, the obtained gametes and the planozyogtes were 
122 also photographed. Data on the life cycle of this dinoflagellate and detailed biometry of

123 different stages was published in Zmerli Triki et al. (2015).

124

125

\subsection{Algal cultures}

126 One monoclonal culture of Alexandrium pseudogonyaulax was obtained from the germination

127 of a wild resting cyst (strain APBZ12) and used for molecular identification and toxin 128 characterization, this culture provided relatively high cell densities required for the 129 subsequent analyses. The stock culture was maintained in sterile flasks filled with $200 \mathrm{~mL}$ of 130 ENSW medium at stable conditions of salinity 34 , temperature $20^{\circ} \mathrm{C}$, irradiance of $100 \mu \mathrm{mol}$ 131 photons $\mathrm{m}^{-2} \mathrm{~s}^{-1}$ using cool white fluorescent light on a 12:12 light:dark cycle.

\subsection{Molecular identification and phylogeny}

\subsubsection{DNA extraction and PCR}

135 Total genomic DNA was extracted from the strain APBZ12 (centrifuged pellets of $100 \mathrm{ml}$

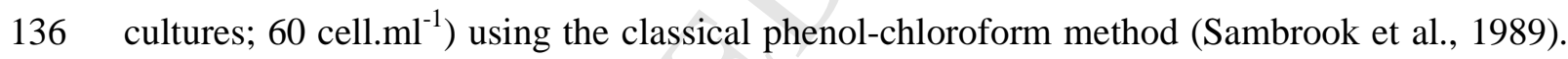

137 Cellular material was released by enzymatic lysis using proteinase K digestion. The DNA was

138 separated from protein by phenol:chloroforme:isoamyl alcohol (25:24:1) extraction then

139 extracted using chloroform:isoamyl alcohol (24:1). The separation of the aqueous and organic

140 phases was performed by centrifugation. The aqueous phase contains the DNA which was

141 ultimately recovered in solid form as a result of precipitation in ethyl alcohol. DNA was then

142 resuspended on ultra pure water. For PCR, the oligonucletide primers and methods used were

143 those described in Nézan et al. (2014). 
145

146

147

148

149

150

151

152

153

154

155

156

157

158

160

161

162

163

164

165

166

167

168

169

\subsubsection{Phylogeny}

For the phylogenetic analysis, the sequence of the Bizerte strain (APBZ12) was aligned together with 41 LSU sequences of other Alexandrium species and one sequence of Goniodoma polyedricum (as outgroup) retrieved from GenBank using the multiple sequence alignment program MUSCLE version 3.7 (Edgar, 2004). The alignment was refined by eye. The data matrix obtained (42 LSU rDNA sequences, 657 characters) was analyzed by two methods of phylogenetic reconstruction: maximum likelihood (ML), using PhyML v.3.0 software (Guindon and Gascuel, 2003) and Bayesian inference (BI) using MrBayes v.3.1.2 (Ronquist and Huelsenbeck, 2003). The software jModeltest v 0.1.1 (Posada, 2008) was first used to select the most suitable model of substitutions. The General-Time Reversible model $(\mathrm{GTR}+\mathrm{I}+\mathrm{G})$ was chosen as indicated by the Hierarchical Likelihood Ratio Tests (hLRTs), Akaike Information Criterion 1 (AIC1), Akaike Information Criterion 2 (AIC2) and Bayesian Information Criterion (BIC) tests implemented in jModeltest. Bootstrap values (support for branches) of trees were obtained after 1000 iterations in ML. For Bayesian inference, four Markov chains were run simultaneously for $2 \times 10^{6}$ generations with sampling every 100 generations. On the $2 \times 10^{4}$ trees obtained, the first 2000 were discarded (burn-in) and a consensus tree was constructed from the remaining trees. The posterior probabilities corresponding to the frequency with which a node is present in preserved trees, were calculated using a coupled Monte Carlo Metropolis approach - Markov Chain (MCMC).

\subsection{Goniodomin A extraction, bioactivity and identification}

\subsubsection{Extract preparation}

Alexandrium pseudogonyaulax culture was harvested in the exponential phase of growth, approximately 12 days after the start of batch culture. The cells were centrifuged (5000 g, 4 min) and the pellets frozen at $-20{ }^{\circ} \mathrm{C}$ before shipping to the NOAA Hollings Marine 
170 Laboratory Emerging Toxins Program (Charleston, SC). For toxin extraction/identification

171 and bioactivity testing, the pellets containing A. pseudogonyaulax cells were sharp frozen and

172 lyophilized. The residual cell powder was extracted using an elutropic series of solvents of 173 increasing polarity: 1) Acetone, 2) Methanol and 3) Water. All were taken to dryness prior to 174 HPLC and or TLC purification/ analysis and then re-suspended in ethyl acetate (EtOAC) for 175 loading on the TLC

\subsubsection{Preparative thin layer chromatography $(T L C)$}

178 The crude concentrated ethyl acetate extract of A. pseudogonyaulax was loaded on Whatman

179 Silica Gel 60A preparative TLC glass-backed plate and then developed in a mixture of 7:3

180 ethyl acetate:benzene. All colored and non-colored bands were scraped from the plate, eluted

181 with ethyl acetate, concentrated and tested for cytotoxicity. These bioassays used methanol as

182 a carrier against the GH4C1 rat pituitary cells and an MTT dye as determining the endpoint

183 (Mosmann, 1983). This procedure both established the Rf value of the toxic compound and

184 effectively separated the toxin from contaminating pigments. A modified molybdic acid stain

185 (Stahl, 1965; $\mathrm{H}_{2} \mathrm{SO}_{4}$ ) was used in addition to cytotoxicity testing in order to associate activity

186 to colored and/or non-colored bands

187

\subsubsection{GH4C1 rat pituitary cytotoxicity bioassay}

189 Bioactivity was determined only from the acetone extract using the GH4C1 bioassay

190 (Mosmann 1983) described in Hsia et al. (2006). Determination of cytotoxicity was carried

191 out following the procedure in Hsia et al. (2006) using rat pituitary cells GH4C1 (ATCC

192 CCL-82.2) in a MTT colorimetric assay (Manger et al., 1993; Mosmann, 1983). GH4C1 rat

193 pituitary cells were plated onto a 96- well plate and allowed to incubate for $18 \mathrm{~h}$ to allow for

194 adherence to the plate. Dried fractions to be tested were solubilized in $100 \mu \mathrm{L}$ methanol and 
195 sonicated to ensure maximum solubility prior to carrying out the bioassay. The assay was

196 carried out by adding $4 \mu \mathrm{L}$ of the methanol-solubilized fractions to individual wells in the 96-

197 well plate; $4 \mu \mathrm{L}$ or less of pure methanol has been previously tested to be safe to these cells

198 (i.e., a negative control). The plate was then allowed to incubate for a minimum of $18 \mathrm{~h} ; 15$

$199 \mu \mathrm{L}$ of 3-(4,5-cimethylthiazol-2-yl)-2,5-diphenyl tetrazolium bromide (MTT) dye was added

200 after incubation and allowed to incubate for another $4 \mathrm{~h}$ before adding $100 \mu \mathrm{L}$ of SDS to each

201 well. The plate was allowed to stand for another $4 \mathrm{~h}$ prior to reading the assay.

\subsubsection{Goniodomin A identification}

204 The bioactive fraction(s) were syringe filtered and then subjected to HPLC/MS purification 205 and analyses to separate, detect and identify toxic extracts from the natural pigmented extracts produced from A. pseudogonyaulax. HPLC/MS purification and analysis was carried out using a WATERS HPLC system (WATERS 2767 Sample Manager), 1525 Binary Pump, 510 pump, WATERS 2996 PDA and a WATERS ZQ Single Quadrapole Mass Detector outfitted with an active flow splitter, switching valve and using MASS LYNX software (Waters

210 Corporation, Milford, MA). The HPLC chromatography was performed using a Luna C18

211 column $(2.5 \mu$ particle size, $2.0 \times 100 \mathrm{~mm})$ (Phenomenex, Torrance, CA) using a reverse-

212 phase water/ACN gradient with $0.1 \%$ TFA in each solvent. The HPLC/MS data (retention

213 time and mass m/z (M+H: 769) was identical to that of goniodomin A as reported in Hsia et 214 al. (2006). Confirmation was carried out by treating the toxic extract with $\mathrm{NaCl}$ and re215 assessing the MS data. As predicted the sodium salt adduct of GDA (M+NA) was generated 216 almost quantitatively. Accurate mass detection of the A. pseudogonyaulax toxic extract was 217 performed using direct infusion of the sample into a Waters Micromass Quadrupole Q-TOF 218 mass spectrometer operating with electrospray ionization in positive ion mode. $\mathrm{KBr}$ and $\mathrm{NH} 4$ 
219

220

221

222

223

224

225

226

227

228

229

230

231

232

233

234

235

236

237

238

239

240

241

242

243

were added in order to test for adduct formation. Chemical formulae were calculated utilizing the elemental composition tools within the Waters Masslynx software.

\section{RESULTS}

\subsection{Morphology of Alexandrium pseudogonyaulax}

Observed under the light microscope, the resting cysts (RCs) of A. pseudogonyaulax from Bizerte lagoon sediment exhibit different sizes and wall thickness. This variability can result in underestimation when quantifying these cysts. More than $200 \mathrm{RCs}$ of A. pseudogonyaulax with different morphologies were incubated to ensure the reliability of our determination of $A$. pseudogonyaulax cysts (Fig. 2). RCs were slightly spherical with one flattened side (Fig. 2A, B). Cyst content was mostly dark and vesicular (Fig. 2C). We also observed clear cysts with brownish-yellow vesicular content (Fig. 2D) with the characteristic red body of Alexandrium species. The cyst wall can be paratabulated or smooth, thin or large (Fig. 2E, F, G). Cysts may produce a diploid planomeiocyst, or two or four haploid vegetative cells (Fig. 2H, I, J, K). Cysts diameter ranged from 40 to $72.5 \mu \mathrm{m}(\mathrm{n}=200)$ with an average of $62.5 \mu \mathrm{m}(\mathrm{SE} \pm 3.65)$. Laboratory produced cysts had vesicular dark content (Fig. 2P).

Excysted vegetative cells of $A$. pseudogonyaulax are thecate, medium to large in size, irregularly pentagonal-shaped with moderate dorso-ventral flattening. Cells are wider than long; the epitheca is slightly shorter than the hypotheca (Fig. 2M). Mean width ranged between $40.9 \mu \mathrm{m}$ and $46.9 \mu \mathrm{m}$ (Zmerli Triki et al., 2014). In the culture, smaller cells were identified as gametes while larger ones corresponded to planozygotes with two longitudinal flagella (Fig. 2N, O). The examination of the plate formula of the strain APBZ12 attested of A. pseudogonyaulax (Biecheler) Horiguchi ex Yuki et Fukuyo. The first apical plate (1') is characteristically displaced with a large ventral pore on the anterior margin. Thecal plates are smooth and thin with scattered minute pores, and their shape and pattern are designed in Fig. 
2443 and are in agreement with the description of A. pseudogonyaulax according to Balech 245 (1995).

\subsection{Ribotyping and phylogeny}

248 A sequence of 703 base pairs has been obtained from the APBZ12 strain, comprising the 249 partial LSU rDNA (D1-D2) and deposited in Genbank with the accession number 250 KT229568. This sequence was similar with a batch of sequences from New Zealand, Japan, 251 China, Norway and Denmark available in Genbank and all identified as A. pseudogonyaulax. 252 The phylogeny inferred from LSU rDNA showed that all these sequences clustered in a 253 highly supported clade which indicated that the LSU of the strain from Bizerte lagoon is 254 identical to the strains also found in New Zealand, Japan, China and in North Sea (Norway 255 and Denmark) (Fig. 4).

256

\subsection{Bioactivity and toxin identification}

258 Purification using preparative thin layer chromatography separated the toxic component from 259 pigments also produced by A. pseudogonyaulax. Pigments such as peridinin and xanthophylls 260 are cytotoxic in high concentrations. This extract was tested positive against the GH4C1 rat 261 pituitary cell line cytotoxicity bioassay. The active compound(s) were eluted from the 262 preparative TLC plate and taken for further purification and characterization on MS and LC263 MS. The molecular ion of GDA (m/z M+H 769) (Fig. 5A) is clearly demonstrated in the 264 active fraction. The HPLC retention time (not shown), and mass (m/z M+H 769) were 265 identical to that of GDA as reported in Hsia et al. (2006). Active fraction shown in Fig. 5B 266 was treated with excess $\mathrm{NaCl}$ generating the (m/z M+Na) sodium adduct of GDA $791.4 \mathrm{amu}$, 267 as predicted and reported in Hsia et al. (2006). All mass spectra were obtained in positive ion 268 mode. The chemical formula of GDA is shown in Fig. 6. 


\section{DISCUSSION}

271 Morphological and molecular analyses performed on APBZ12 strain confirmed the 272 identification of Alexandrium pseudogonyaulax. Moreover, it showed that this strain 273 originating from Bizerte (Mediterranean) is $100 \%$ identical with strains of this species 274 isolated from New Zealand, Japan, China and North Sea (Norway and Denmark). 275 Alexandrium pseudogonyaulax therefore occurs worldwide including a semi-enclosed South276 Western Mediterranean lagoon (Bizerte). This wide distribution could be explained by natural 277 or human assisted dispersion throughout resting cysts transport by water ballast and/or 278 shellfish (Hallegraeff, 1993, Laabir et Gentien, 1999) or/and the large geographical 279 occurrence of an endogenous species. The life cycle of A. pseudogonyaulax showed a 280 succession of different stages with distinctive morphology, physiology and function. Asexual 281 reproduction was characterized by eleutheroschisis where a vegetative cell sheds its theca 282 when settling on surface sediment, thereafter the resulting temporary cyst divides. Two types 283 of conjugation of the gametes were observed in A. pseudogonyaulax including engulfment 284 and fusion either with anisogamy or isogamy leading to the planozygote (Zmerli Triki et al., 285 2015). The morphology of vegetative cells was consistent with the general features of the 286 species and they are described with more details in Zmerli-Tiki et al. (2014). Resting cysts 287 (RCs) have different appearance, which can misleading in quantitative and qualitative studies. 288 Compared to A. pseudogonyaulax cysts (40 to $50 \mu \mathrm{m}$ in diameter) described by Bravo et al. 289 (2006), mean cyst diameter of APBZ12 was $62.5 \mu \mathrm{m}(\mathrm{SD} \pm 3.65)$. Most of $A$. 290 pseudogonyaulax RCs encountered in this study were paratabulated, whereas others showed 291 no tabulation at all or very fine tabulation hardly distinguished under photonic microscope.

292 The misidentification of Alexandrium hiranoi blooming on Jogashima, Japan (Murakami 293 et al., 1988) as Alexandrium pseudogonyaulax (Kita et al., 1985) producing GDA caused a 
294 taxonomic confusion about A. pseudogonyaulax toxicity. Kita and Fukuyo (1988) renamed

295 formerly the dinoflagellate species producing GDA in Jogashima as A. hiranoi. However, 296 unfortunately the confusion remained in many works dealing with GDA toxin (Mizuno et al., 297 1998; Matsunaga et al., 1999; Abe et al., 2002; Takeda et al., 2008).

298 To our knowledge, no study was conducted on well characterized strains of $A$. 299 pseudogonyaulax to highlight any potential toxicity. The present work showed 300 unambiguously using HPLC-MS, that A. pseudogonyaulax (APBZ12) produces GDA, the 301 same toxin produced by A. monilatum from the Gulf Coast of the United States (Hsia et al., 302 2006) as well by A. hiranoi isolated from a Japanese rock pool (Murakami et al., 1988).

303 This toxin could be responsible of harmful effects on human health and aquatic fauna. Mizuno 304 et al. (1998) reported that GDA affects human cell brain functioning causing morphological 305 changes in astrocytomas cells by increasing the filamentous actin content. Also, GDA was 306 reported to inhibit angiogenesis (regeneration of vessel) and that this was mediated at least in 307 part through the inhibition of actin reorganization (Abe et al., 2002). During A. monilatum 308 bloom in the lower York River, significant mortality of Veined rapa whelks (Rapana venosa, 309 gastropods) was observed and GDA concentration was around $0.77-8.77 \mathrm{mg}$ toxin $\mathrm{g}^{-1}$ of 310 whelk tissue (Harding et al., 2009). Massive fish mortalities reported for over than 100 years 311 in the Offats Bayou near Galveston, Texas (USA) have been associated to the GDA producer 312 A. monilatum (Gates and Wilson, 1960, Hsia et al., 2006). This mortality was probably due to 313 haemolytic activity of the produced polyether macrolide (Clemons et al., 1980; Bass et al., 314 1983).

315 At our knowledge, no blooms nor fish or mollusk mortalities have been yet associated with $A$. 316 pseudogonyaulax from Bizerte. Monitoring programs on shellfish mortality is not yet 317 implemented and aquaculture farms in Bizerte are rather uncommon. However, in view of the 318 development of aquaculture activities and in regards of the significant cyst densities (Zmerli 
319 Triki et al., 2014) in the sediment which are able to germinate and inoculate the water column,

320 this lagoon is not immune to major development of this toxic dinoflagellate which could

321 potentially cause the intoxication and the mortality of the wild fish and cultivated mollusks.

322 Thus the existing monitoring program have to include A. pseudogonyaulax in HAB species

323 list and GDA analyzes have to be performed when this dinoflagellate bloomed in the 324 concerned marine ecosystem.

\section{CONCLUSION}

327 We have demonstrated that A. pseudogonyaulax produces the toxic compound goniodomin A.

328 This toxin is similar to that produced by A. monilatum and A. hiranoi developing in

329 contrasting marine systems. We also showed that the mass extract of APBZ12 was highly

330 bioactive which suggest a possible lethal effect on fishes in situ when algal cells are disrupted.

331 Further studies have to focus on the ecology and population dynamic of this species to better 332 understand the main environmental factors regulating its development in situ.

333 Ecophysiological studies have to investigate the modulation of the production of GDA by the

334 environmental factors such temperature, salinity and nutrients (organic and inorganic nitrogen

335 and phosphate). Because of the demonstrated bioactivity of GDA from APBZ12, it will be

336 interesting to investigate the effect of this toxin on the major component of eleutheroschisis

337 where a vegetative cell sheds its theca when settling on surface sediment, thereafter the

338 resulting temporary cyst divides the marine ecosystem as fishes, mollusks and zooplankton

339 and to highlight the transfer of this potent toxin to high trophic levels.

\section{ACKNOWLEDGEMENTS}

342 This work benefitted from financial supports of the JEAI ECOBIZ (Jeune Equipe Associée,

343 Ecologie de la lagune de Bizerte) program and LMI COSYS-MED funded by IRD (Institut 
344 Français pour la Recherche et le Développement) and from LAGUNTOX project funded by

345 TOTAL Foundation. Thanks to IRD for funding M. LAABIR stay in Tunisia. The

346 Toxin/Natural Products Chemistry Program (NOAA, USA) provided support and analysis of

347 toxins. The authors wish to thank G. Bilien for DNA amplification and sequencing. 


\section{REFERENCES}

349

Abe, M., Inoue, D., Matsunaga, K., Ohizumi, Y., Ueda, H., Asano, T., Murakami, M., Sato, Y., 2002. Goniodomin A, an antifungal polyether macrolide, exhibits antiangiogenic activities via inhibition of actin reorganization in endothelial cells. J. Cell. Physiol. 192, 109-116.

354

355

356

Anderson, D.M., Alpermann, T.J., Cembella, A.D., Collos, Y., Masseret, E., Montresor, M., 2012. The globally distributed genus Alexandrium: Multifaceted roles in marine

Balech, E., 1995. The Genus Alexandrium Halim (Dinoflagellata), Sherkin Island Marine ecosystems and impacts on human health. Harmful Algae. 14, 10-35.

361

362

Biecheler, B., 1952. Recherches sur les Péridinens. Bull. Biol. France Belgique Suppl. 36, 1-

Bolch, C.J.S., 1997. The use of sodium polytungstate for the separation and concentration of living dinoflagellate cysts from marine sediments. Phycologia. 36, 472-478 of the toxigenic dinoflagellate genus Alexandrium in recent sediments from the Western Mediterranean coast, including the first description of cysts of A. kutnerae and A. peruvianum. Eur. J. Phycol. 41(3), 293-302 
373 Blossom, H.E, Daugbjerg, N., Hansen, P.J., 2012. Toxic mucus traps: A novel mechanism

374 that mediates prey uptake in the mixotrophic dinoflagellate Alexandrium pseudogonyaulax.

375 Harmful Algae. 17, 40-53

376

377 Connell, C.H., Cross, J.B., 1950. Mass mortality of fish associated with the protozoan 378 Gonyaulax in the Gulf of Mexico. Science. 112, 359-363.

379

380 Daly Yahia-Kefi, O., Nézan, E., Daly Yahia, M.N., 2001. Sur la présence du genre 381 Alexandrium Halim (Dinoflagellés) dans la baie de Tunis (Tunisie). Oceanol. Acta. 24, 1738225.

383

384 Edgar, R.C., 2004. MUSCLE: multiple sequence alignment with high accuracy and high 385 throughput. Nucleic Acids Res. 32, 1792-1797.

386

387 Gates, J.A., Wilson, W.B., 1960. The toxicity of Gonyaulax monilata Howell to Mugil 388 cephalus. Limnol. Oceanogr. 5, 171-174.

389

390 Guindon, S., Gascuel, O., 2003. A Simple, Fast, and Accurate Algorithm to Estimate Large 391 Phylogenies by Maximum Likelihood. 52, 696-704

392

393 Hallegraeff, G.M., 1993. A review of harmful algal blooms and their apparent global increase.

394 Phycologia. 32, 79-99. 
396

397

398

399

400

401

402

403

404

405

406

407

408

409

410

411

412

413

414

415

416

417

418

419

Harding, J.M., Mann, R., Moeller, P., Hsia, S.M., 2009. Mortality of the veined Rapa whelk, Rapana venosa, in relation to a bloom of Alexandrium monilatum in the York river, United States. J. Shell. Res. 28, 363-367.

Harrison, P.J., Waters, R., Taylor, F.J.R., 1980. A broad spectrum artificial seawater medium for coastal and open ocean phytoplankton. J. Phycol. 16, 28-35.

Hsia, M.H., Morton, S.T., Smith, L.L., Beauchesne, K.R., Huncik, K.M., Moeller, P.D.R., 2006. Production of goniodomin A by the planktonic, chain-forming dinoflagellate Alexandrium monilatum (Howell) Balech isolated from the Gulf Coast of the United States. Harmful Algae. 5, 290-299

Howell, J.F., 1953. Gonyaulax monilata, sp. nov., the causative dinoflagellate of a red tide on the east coast of Florida in August-September, 1951. Trans. Am. Micro. Soc. 72, 153156.

Kita, T., Fukuyo, Y., 1988. Description of gonyaulacoid dinoflagellate Alexandrium hiranoi sp. nov. inhabiting on Japanese Pacific coast. Bull. Plankton Soc. Japan 35:1-7

Kita, T., Fukuyo, Y., Tokuda, H., Hirano, R., 1985. Life history and ecology of Goniodoma pseudogonyaulax (Pyrrhophyta) in a rockpool, Bull. Mar. Sci. 37, 643-651.

420 
421 Laabir, M., Gentien, P., 1999. Survival of toxic dinoflagellates after gut passage in the pacific 422 oyster Crassostrea gigas Thunberg. J. Shellfish Res. 18, 217-222.

423

424 Manger, R., Leja, L.S., Lee, S.Y., Hungerford, J., Wekell, M., 1993. Tetrazolium-based cell 425 bioassay for neurotoxins active on voltage-sensitive sodium channels: semiautomated 426 assay for saxitoxins, brevetoxins, and ciguatoxins. Anal. Biochem. 214, 190-194.

Matsunaga, K., Nakatani, K., Murakami, M., Yamaguchi, K., Ohizumi, Y., 1999. Powerful activation of skeletal muscle actomyosin ATPase by goniodomin A is highly sensitive to troponin/tropomyosin. J. Pharm. Exp. Ther. 291 (3), 1121-1126.

Mizuno, K., Nakahata, N., Ito, E., Murakami, M., Yamaguchit, K., Ohizumi., Y. 1998. Goniodomin A, an Antifungal Polyether Macrolide, Increases the Filamentous Actin Content of 1321N1 Human Astrocytoma Cells. J. Pharm, Pharmacol. 50, 645-448.

Montresor, M., 1995. The life history of Alexandrium pseudogonyaulax (Gonyaulacales, Dinophyceae). Phycologia. 34, 444-448.

Mosmann, T., 1983. Rapid colorimetric assay for cellular growth and survival: application to proliferation and cytotoxicity assays. J. Immunol. Methods 65, 55-63.

Murakami, M., Makabe, K., Yamaguchi, S., Konosu, S., Walchi, R., 1988. Goniodomin A, a 443 novel polyether macrolide from the dinoflagellate Goniodoma pseudogoniaulax. 444 Tetrahedron Lett. 29, 1149-1152. 
446 Nézan, E., Siano, R., Boulben, S., Six, C., Bilien, G., Cheze, K., Duval, A., Le Panse,

447 S., Quere, J., Chomerat, N., 2014. Genetic diversity of the harmful family Kareniaceae

448 (Gymnodiniales, Dinophyceae) in France, with the description of Karlodinium gentienii

449 sp. nov.: A new potentially toxic dinoflagellate. Harmful Algae. 40, 75-91.

450

451 Posada, D., 2008. jModelTest: phylogenetic model averaging. Mol. Biol. Evol. 25, 1253$452 \quad 1256$.

453

454

455

Ronquist, F., Huelsenbeck, J.P., 2003. MrBayes 3: Bayesian phylogenetic inference under

456 mixed models. Bioinformatics. 19 (12), 1572-1574.

457 Sambrook, J., Fritschi, E.F., Maniatis, T., 1989. Molecular cloning: a laboratory manual, Cold 458 Spring Harbor Laboratory Press, New York.

459

Sievers, A.M., 1969. Comparative toxicity of Gonyaulax monilata and Gymnodinium breve to annelids, crustaceans, mollusks, and a fish. J. Protozol. 16 (3), 401-404.

462

463 Stahl, E., 1965. Thin-Layer Chromatography: A Laboratory Handbook. second ed. Academic 464 Press Inc. Publishers, NY.

465

466 Takeda, Y., Shi, J., Oikawa, M., Sasaki, M., 2008. Assignment of the Absolute Configuration 467 of Goniodomin A by NMR Spectroscopy and Synthesis of Model Compounds. Org. Lett. $468 \quad 10,1013-1016$ 
470 Throndsen, J., Hasle, G.R., Tangen, K., 2007. Phytoplankton of Norwegian coastal waters. $471 \quad$ Almater For lag AS, Oslo. 343 p.

472

473 Turki, S., 2004. Suivi des microalgues planctoniques toxiques dans les zones de production, 474 d'élevage des mollusques bivalves et d'exploitation des oursins du nord de la Tunisie, 475 Bull. Inst. Natn. Sci. Tech. Mer Salammbô. 31, 83-96.

476

477 Sharma, GM., Michaels, L., Burkholder, PR., 1968. Goniodomin, a new antibiotic from a 478 dinoflagellate. J antibiot. 21, 659-664.

479

480

Zmerli Triki, H., Kefi Daly-Yahia, O., Malouche, D., Komiha, Y., Deidun, A., Brahim, M., 481

482

483 Laabir, M., 2014. Resting cysts distribution of the potentially toxic dinoflagellate Alexandrium pseudogonyaulax in recent sediment of Bizerte Lagoon (Mediterranean coast, Tunisia). Mar. Pollut. Bull. 84, 172-181.

484

485

Zmerli Triki, H., Laabir M., Kefi Daly-Yahia, O., 2015. Life history, excystment features and 486 growth characteristics of the Mediterranean harmful dinoflagellate Alexandrium pseudogonyaulax. J. Phycol. 51, 980-989. DOI : 10.1111/jpy.12337

488

489

490

491

492

493 
494

495

496

497

498

499

500

501

502

503

504

505

506

507

508

509

510

511

512

513

514

515

516

517

518

\section{FIGURE CAPTIONS}

Fig. 1. Map of the Bizerte lagoon showing connections with Ichkeul lake and Mediterranean sea.

Fig. 2. Alexandrium pseudogonyaulax resting cysts (RCs) morphotypes isolated from recent sediments of Bizerte lagoon and life history stages: flattened side of A .pseudogonyaulax RCs (A, D), paratabulated cyst (B-F); thin pellicule mucus in RC (narrow) (E), vesiculos content of A. pseudogonyaulax $\mathrm{RCs}(\mathrm{F}, \mathrm{G})$; granular content of A. pseudogonyaulax $(\mathrm{H})$; RCs with two $(\mathrm{J}, \mathrm{K})$ or four (I) daughter cells inside the cyst; paratabulated empty cyst (L); vegetative cell $(\mathrm{M})$; gamete $(\mathrm{N})$; planozygote $(\mathrm{O})$; laboratory produced resting cysts $(\mathrm{P})$. Scale bar $(10 \mu \mathrm{m})$.

Fig. 3. Alexandrium pseudogonyaulax APBZ12 designed thecal plates (1' to 4' and 1' to 6") of the epitheca, Vp means ventral pore.

Fig. 4. Maximum likelihood phylogenetic tree of Alexandrium pseudogonyaulax inferred from partial LSU rDNA (matrix of 42 taxa and 657 positions). The tree was routed with Goniodoma polyedricum. Filled black circles indicate full statistical support of branches (100/1.00). Values associated with branches correspond to bootstrap support and posterior probabilities (ML/BI).

Fig. 5. (A) MALDI-TOF of toxic extract; 791.23 indicates mass of extract in positive ion mode. (B) ESI-MS of toxic extract; 791.2 indicates mass of extract in positive ion mode

Fig. 6. Chemical structure of goniodomin A (reproduced from Hsia et al., 2006) 
Fig. 1

520

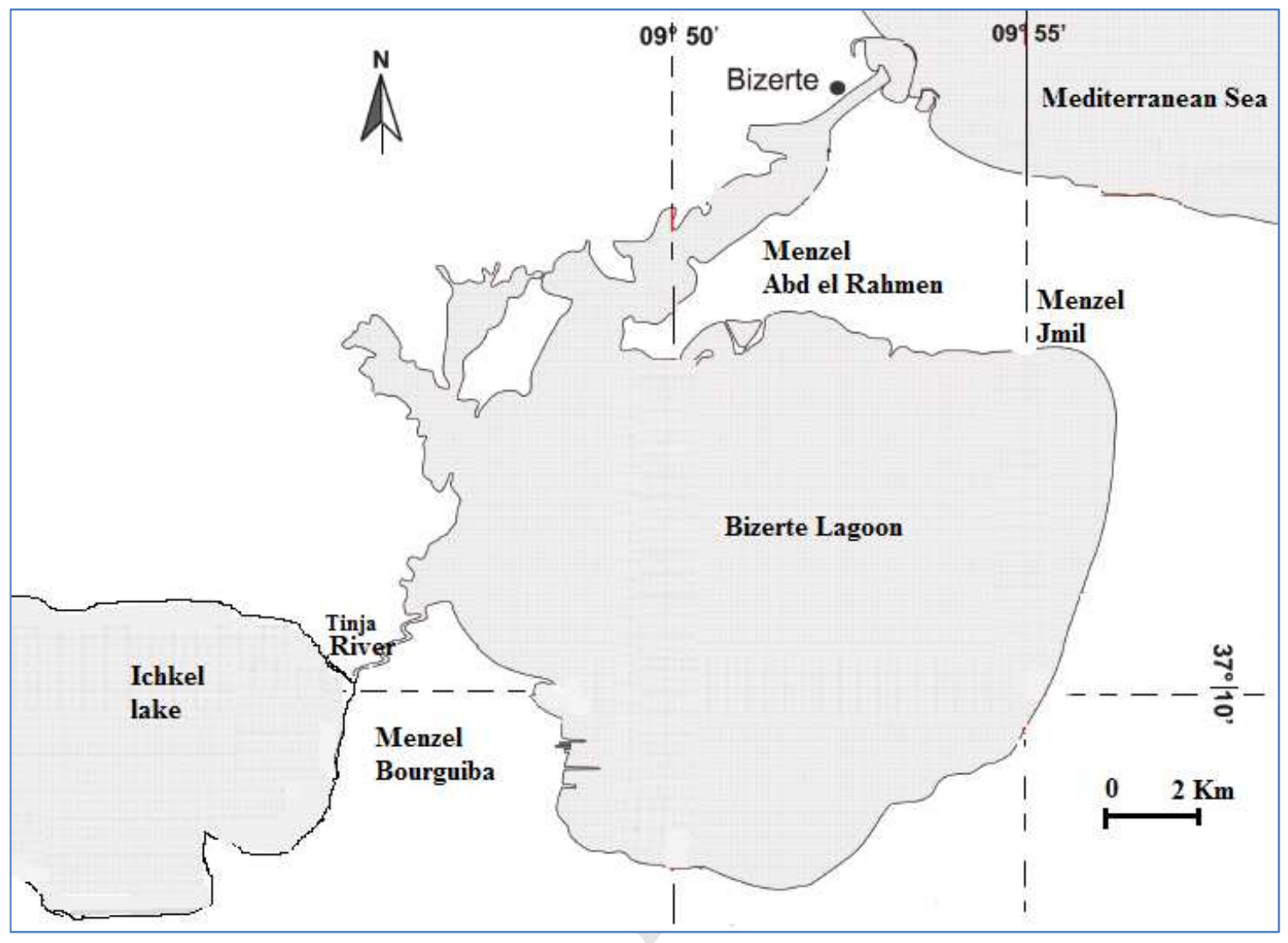

521

522

523

524

525 
Fig. 2

527
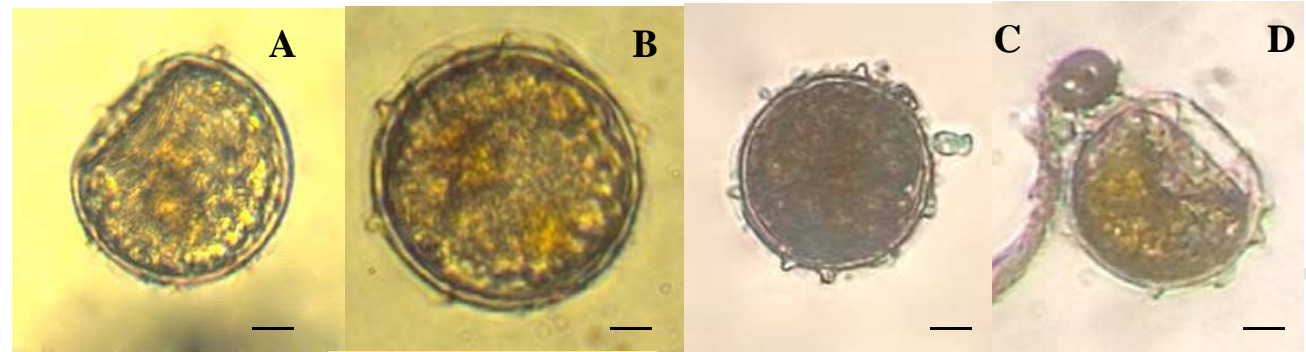

528
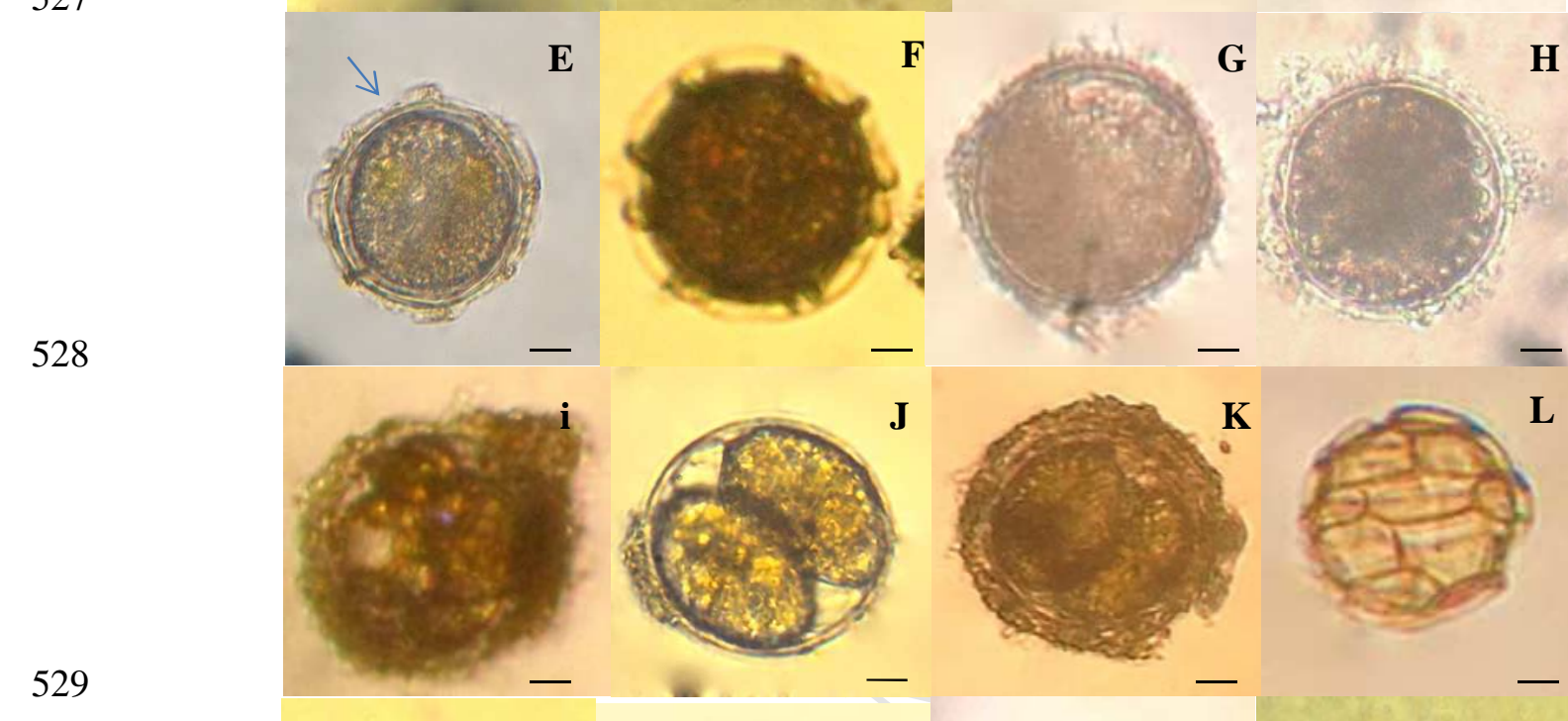

530
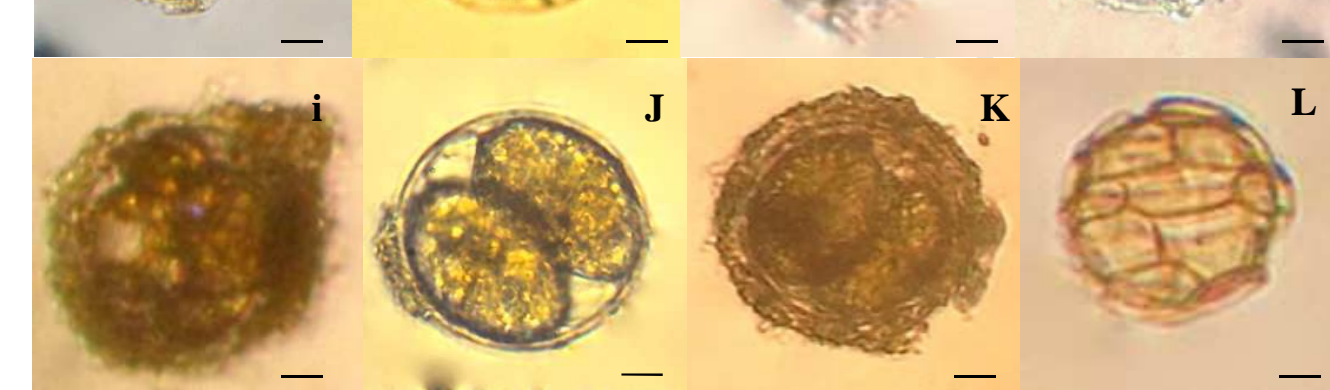

529

531

532

533

534

535

536

537

538

539 
$540 \quad$ Fig. 3

541

542

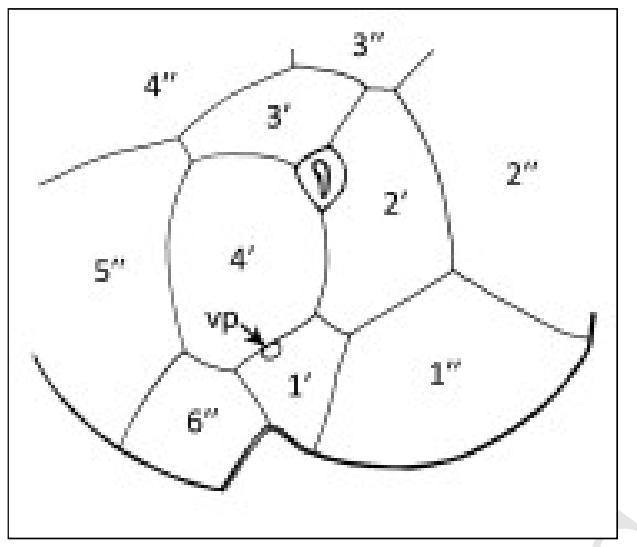

543

544

545 


\section{$546 \quad$ Fig. 4}

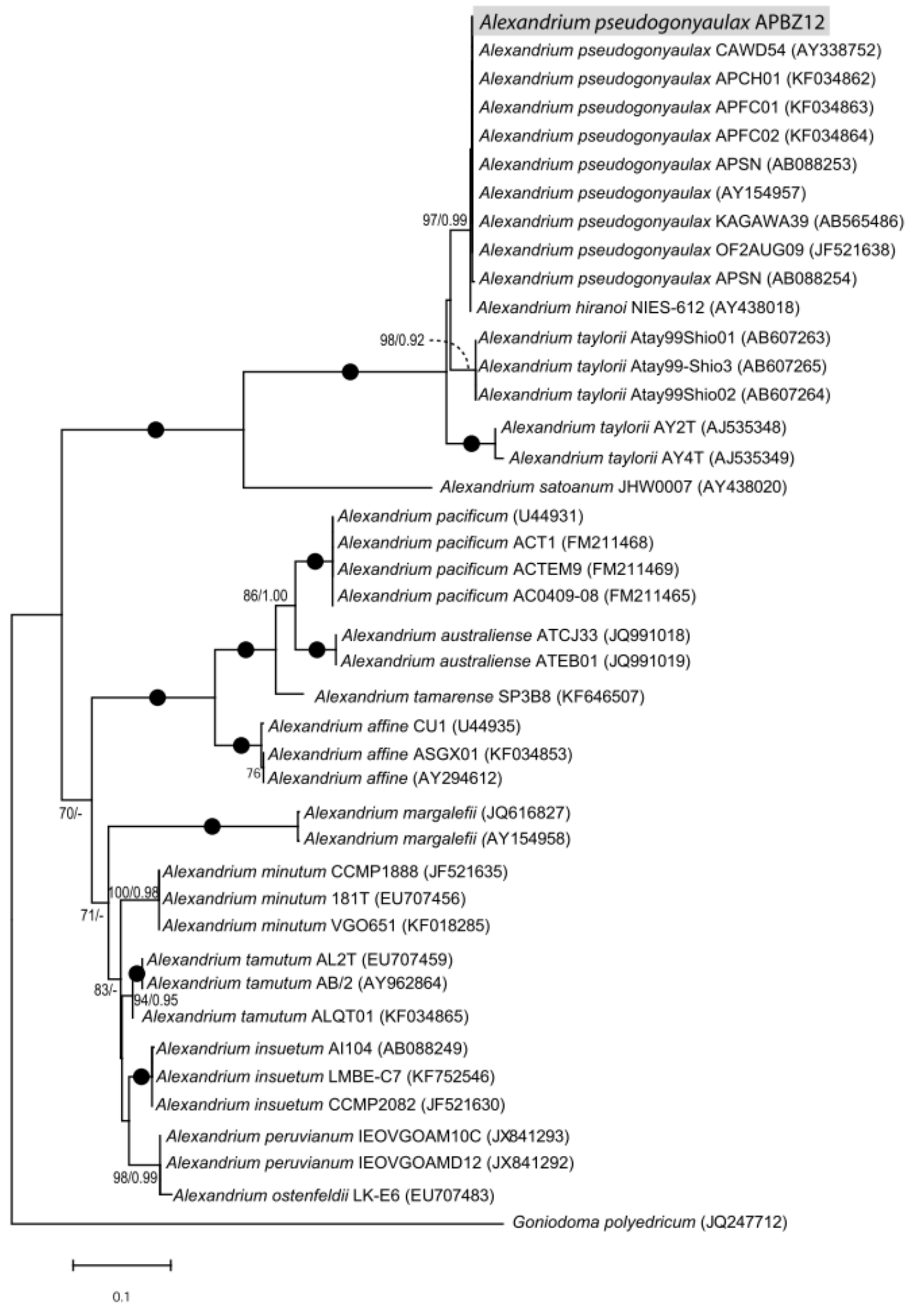


$548 \quad$ Fig. 5A

549

550

\section{Iuna c18} france_1_2 $2965(29.872) \mathrm{Cm}(2841: 2974)$
498.38

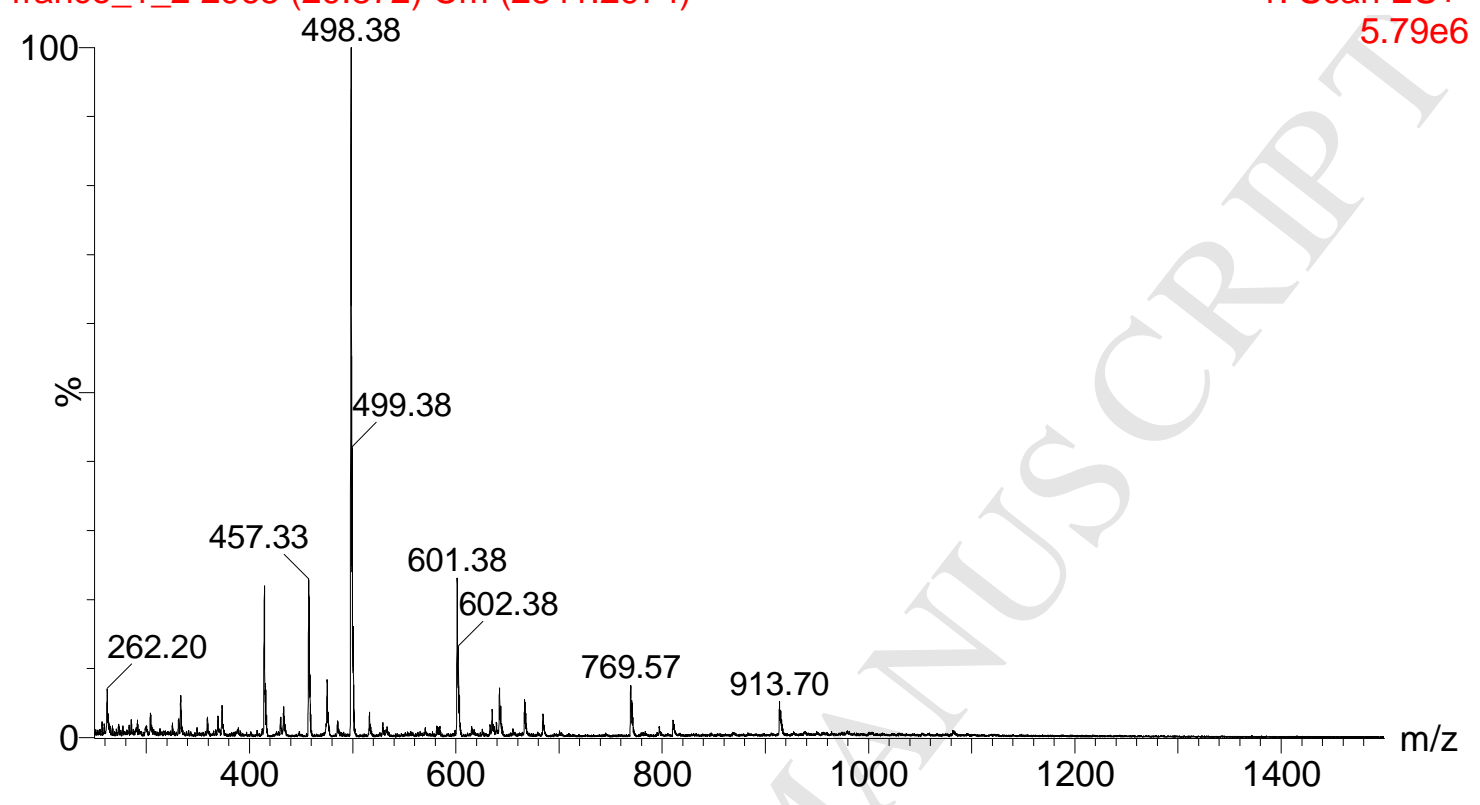

551

552

553

Fig. 5B

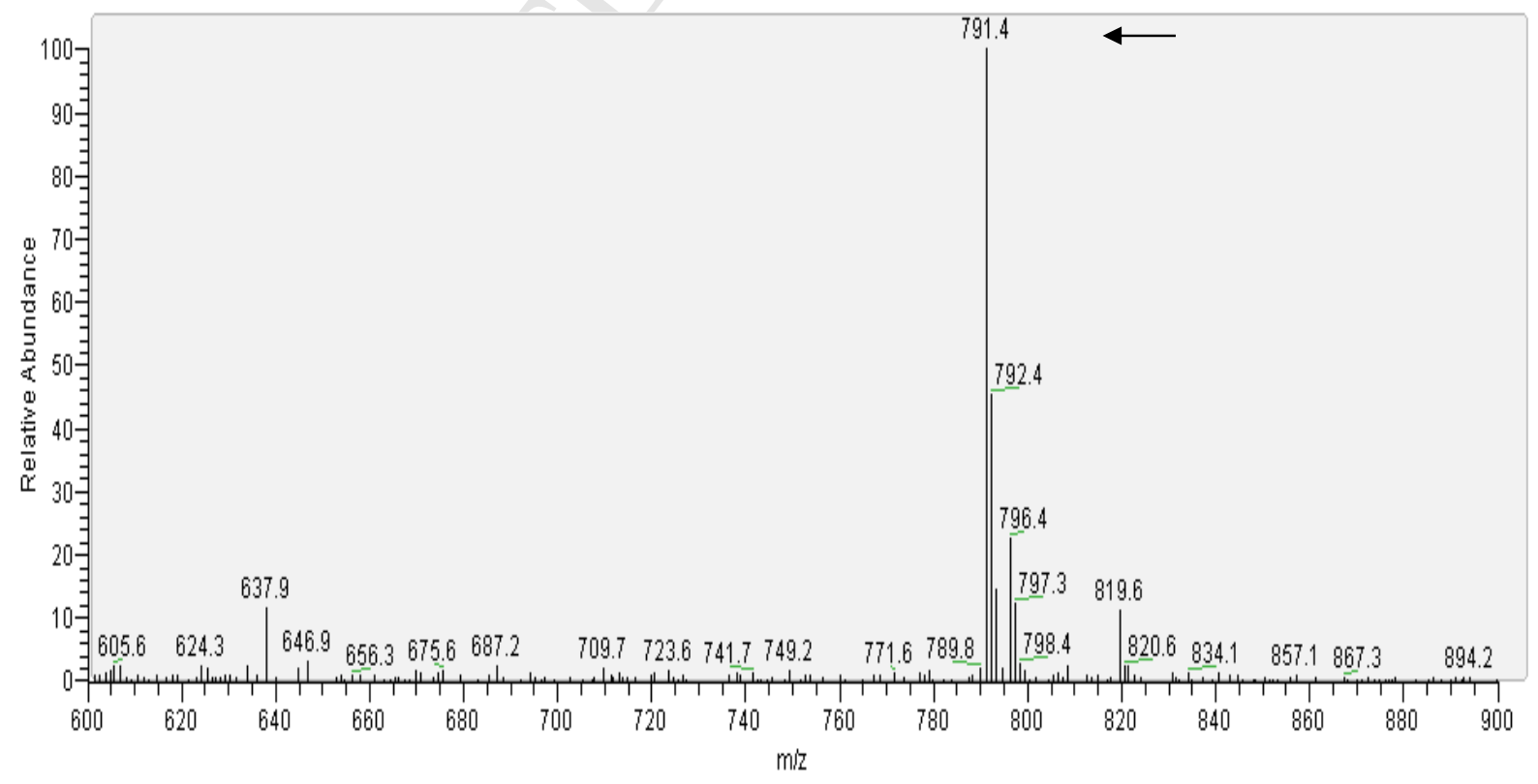


556

Fig. 6

557

558

559

560

561

562

563

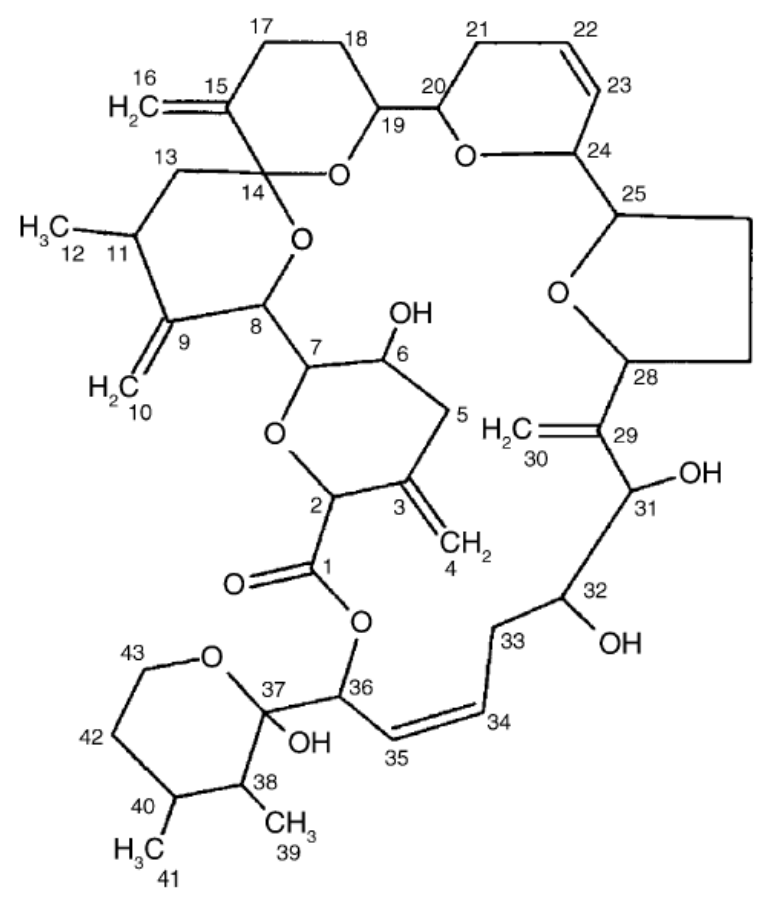

